M.V. Manilo ${ }^{1,2}$, N.I. Lebovka ${ }^{1}$, S. Barany ${ }^{2}$

\title{
A SHORT REVIEW ON REGULATION OF STABILITY OF AQUEOUS SUSPENSIONS OF CARBON NANOTUBES
}

\author{
${ }^{I}$ F.D. Ovcharenko Institute of Biocolloidal Chemistry of National Academy of Sciences of Ukraine \\ 42 Vernadsky Ave., Kyiv, 03142, Ukraine, E-mail: lebovka@gmail.com \\ ${ }^{2}$ University of Miskolc, Research Institute of Applied Earth Sciences \\ and MTA-ME Materials Science Research Group, Hungary,E-mail: akmbsab@uni-miskolc.hu
}

\begin{abstract}
This review analyses the authors' recent and related works on electrokinetic properties and colloidal stability of aqueous suspension of multi-walled carbon nanotubes (CNTs) in the presence of surfactants and nanoparticles. Selected adsorptive properties of carbon nanotubes are also considered.

The applicability of classical theories of electrophoresis for description of electrophoretic mobility of carbon

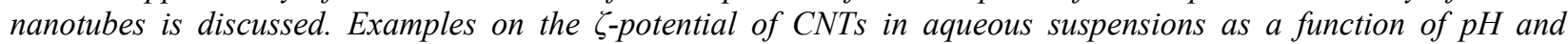
concentration of electrolytes ( $\mathrm{KCl}, \mathrm{CaCl}_{2}$ and $\left.\mathrm{AlCl}_{3}\right)$ are given. Additions of cetyltrimethylammonium bromide $(C T A B)$ cationic surfactant below the critical micelle formation concentration (CMC) values give a reduction and then an overcharging the CNT surface because of accumulation of the surfactant ions in the Stern layer. At

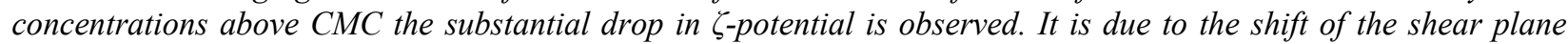
toward solution as a result of formation of hemi-micelles on the surface. An increase in the mass ratio of artificial mineral Laponite (Lap) in suspension $(X)$ from 0 to 0.4 results in a monotonic decrease of the $\zeta$-potential of CNT + Lap hybrids with reaching its plateau value $\approx-32 \mathrm{mV}$ at $X \geq 0.4$ that corresponds to the $\zeta$-potential of "pure" Lap platelets. This evidences the high surface coverage of nanotubes surface with Lap at $X \geq 0.4$.

The major methods to improve the dispersibility of carbon nanotubes, their colloidal stability and adsorptive properties are briefly discussed, namely: stabilization in mixtures of water and organic solvents; functionalization by chemical treatment; stabilization by additives of surfactants or polymers and hybridization by addition of supplementary stabilizing nanoparticles. CNTs can be significantly debundled in "good" solvents, such as 1cyclohexyl-2-pyrrolidone, N,N-dimethylformamide, or N-methyl-2-pyrrolidone. It is demonstrated that the dispersibility of CNTs is a complex function of the type of surfactant, its concentration and the surfactant/CNTs ratio. The optimum concentration of CTAB to achieve homogeneous aqueous dispersion of carbon nanotubes was identified to be near the CMC. Additions of CTAB significantly modify the size distribution of CNTs and a sharp transition from small primary aggregates to large secondary aggregates at concentrations above CMC is observed. At optimal concentration of Lap the nanotube particles get well stabilized, and a stepwise increase of sedimentation stability is observed.

We have shown also that CNT + Lap hybrids can be effectively used for removal of methylene blue dye from aqueous systems. The kinetics and mechanisms of adsorption are elucidated.
\end{abstract}

Keywords: carbon nanotubes, aqueous suspension, colloidal stability, zeta potential, surfactants, hybrids

\section{INTRODUCTION}

The composite materials doped with carbon nanotubes (CNTs) have demonstrated many attractive physico-chemical properties (electrical, magnetic, mechanical, thermal etc.) [1]. On the base of these materials different types of electrochemical biosensors, nanosensors for chemical and biological applications, piezoresistive strain sensors, electrical energy, memory storage devices, and super-capacitors, nanofluids for heat transfer devices, sorbents, materials for nanomedicine and promising biomedical applications, cancer therapy, biopharmaceutics drug delivery and tissue engineering have been proposed.

However, the poor dispersibility of CNTs in most of the solvents and tendency of their aggregation present a serious obstacle for preparation of materials with good functionality. Preparation of CNT products are often realized through use of their stable aqueous suspensions [2]. Commonly, these suspensions possess low colloidal and sedimentation stability. The strong aggregation of CNTs is due to the high surface energy and aspect ratio, presence of strong van der Waals and hydrophobic attractive forces. Moreover, because of high hydrophobicity of CNT surface, the water is a poor solvent for 
preparation of stable aqueous CNT suspensions. The electrical, mechanical and thermal properties of composite materials can be significantly deteriorated by aggregation of CNTs. Therefore, the prevention aggregation and regulation of stability of suspensions of the CNTs is important scientific and technical task. In addition, the colloidal stability of the CNTs may be crucial with respect to the environmental impact of these materials.

In this review we briefly discuss our resent results on electrokinetic properties and colloidal stability of aqueous suspension of carbon nanotubes in the presence of surfactants and nanoparticles. Selected adsorptive properties of carbon nanotubes are also considered.

\section{ELECTROPHORETIC MOBILITY AND ZETA POTENTIAL OF CARBON NANOTUBES}

The electrophoretic mobility of charged particles dispersed in a solution is defined by interaction of their electrical double layers (EDL) with an external field. At relatively low fields (typically several or several dozen $\mathrm{V} / \mathrm{cm}$ ) the velocity of motion $V$ is proportional to the electric field strength $E$, i.e., $V=\mu E$, where $\mu$ is a electrophoretic mobility [3]. Electrophoresis is widely used in colloid and material science, medical and biological applications for characterization of the particles surface, separation of biocolloids, macromolecules, in electrodeposition/electrocoating technologies for fabricating of advanced materials, ion batteries and ceramic coatings [4].

In aqueous systems the electrophoretic mobility is greatly affected by the sort and concentration of electrolytes, and character of ions hydration. Effect of ions can be represented as the Hofmeister or lyotropic series which orders them with respect to macroscopic properties like surface tension, solubility of hydrocarbons, protein denaturation, etc. The Hofmeister series [5] reflect the orders of the ion effect on hydration of anions and cations:

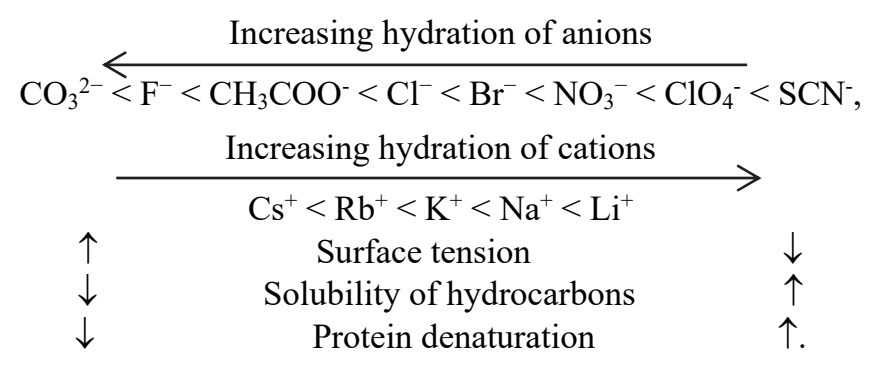

Generally, anions show more specific and more pronounced effects than cations. This distinction can be explained by the fact that anions are commonly bigger and more polarisable than cations. The simple explanation of the Hofmeister series is based on the hydration. Generally, there is no unique Hofmeister series for the electrophoretic mobility, it can depend on the nature of the surface involved (sign of charge, polarity, hydrophilic or hydrophobic nature, etc.), type of electrolyte, $\mathrm{pH}$, temperature and other conditions of the experiment [6]. Depending on parameters, the ordering of the ions within the Hofmeister series can be direct, indirect and partially altered.

The measured electrophoretic mobility $\mu$ may be converted into $\zeta$-potential (zeta potential) using the Smoluchowski's approximation [3] $\zeta=\mu \eta / \varepsilon \varepsilon_{o}=\rho /\left(\varepsilon \varepsilon_{o} \kappa\right)$,

where $\varepsilon$ and $\eta$ are the dielectric constant and dynamic viscosity of the solution, respectively, $\varepsilon_{0}$ is the permittivity of the free space, $\rho$ is the charge density at the slip plane in the EDL, $\kappa=1 / \lambda_{\mathrm{D}}$ is the inverse Debye screening length. The $\zeta$-potential corresponds to the potential drop between the shear plane (i.e. the plane where the abrupt change in the viscosity of liquid adjacent to the surface takes place) and the bulk of solution.

The validity of Smoluchowski's equation assumes that the $\zeta$-potential is distributed uniformly, the local radii of curvature of the particles are much larger than the thickness of the electric double layer $\lambda$ and the electric double layer remains in equilibrium. For heterogeneous charge distribution and for arbitrary shaped 
particles, the relevant corrections to the Smoluchowski's equation are necessary. The theory of electrophoretic mobility was mainly developed for cylindrical, spherical and disk-like particles [7]. However, the proposed models are rather complicated for mathematical analysis of the experimental systems.

In general, the electrophoretic mobility of CNT aggregates cannot be treated in the same manner as for spherical particles due to the large size and possible complexity of the aggregates. For thin double layers, the particles of any shape and size mostly behave very closely to that as expected for

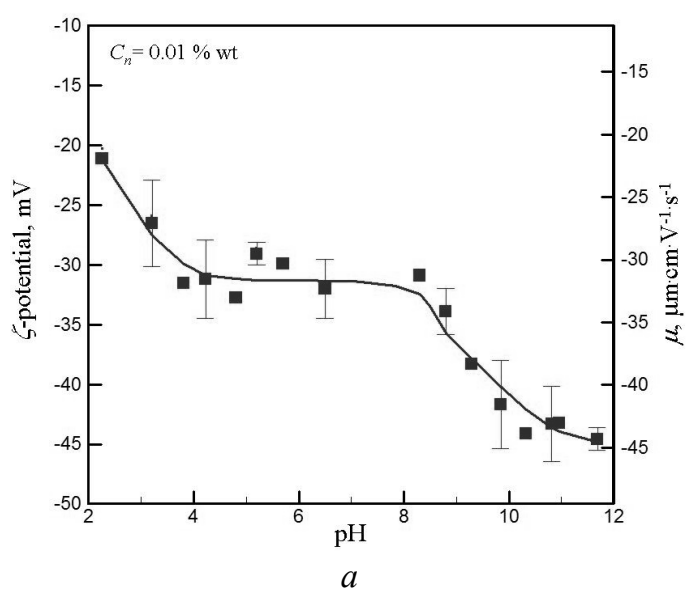

spheres of equivalent volume and charge. In this case, the classical Smoluchowski's equation can be applied for estimation of the "effective" $\zeta$-potential (which is equal to the electrophoretic mobility multiplied by the ratio of the viscosity of the medium to its permittivity) [8], and it becomes even more appropriated for the large aggregates of CNTs. Such a procedure is accepted in the literature, and it can serve for comparison purposes, i.e. to follow the effects of different variables on the electrophoretic mobility and $\zeta$-potential values. The Smoluchowski's equation was widely used for estimation of the effective $\zeta$-potential of CNTs [9].

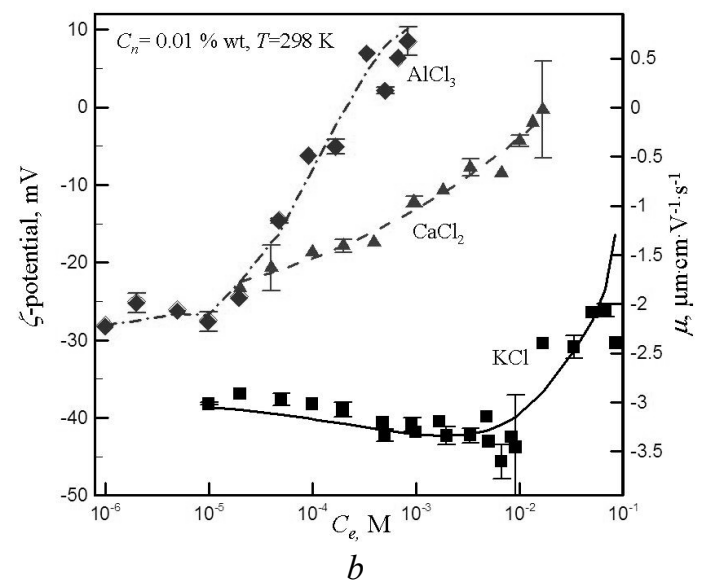

Fig. 1. $\zeta$-potential (the electrophoretic mobility $\mu$ at right axes) of MWCNTs $(0.01 \%$ wt.) in water versus pH (a) and versus concentration of electrolyte, $C$, for $\mathrm{KCl}, \mathrm{CaCl}_{2}$ and $\mathrm{AlCl}_{3}(b)$ (adapted from [10])

The effects of $\mathrm{pH}$ and the validity of the Hofmeister series for suspensions of multiwalled carbon nanotubes (MWCNTs) in water has been checked [10]. Fig. $1 a$ shows an example of the $\mathrm{pH}$ dependence of $\zeta$-potential (and electrophoretic mobility $\mu$ ) of $0.1 \% \mathrm{wt}$. MWCNTs in distilled water. The nanotubes were charged negatively in the whole interval of $\mathrm{pH}$ values $(\mathrm{pH}=2-12)$, and an increase in $\mathrm{pH}$ resulted in a noticeable increase of $\zeta$-potential from $\approx-19 \mathrm{mV}$ at $\mathrm{pH}=2$ to $\approx-44 \mathrm{mV}$ at $\mathrm{pH}=12$. The step-like behavior with near-constant $\zeta$-potential $(\zeta \approx-30 \mathrm{mV})$ in the interval of $\mathrm{pH} 4-8$ was observed. Such behavior can be explained by the impact of $\mathrm{pH}$ on dissociation of weak acidic functional groups on the surface of nanotubes, presumably hydroxyl and carbonyl groups (the presence of such groups was justified by the IR spectroscopy data) [10]. These functional groups (e.g., $-\mathrm{OH}$ and $-\mathrm{COOH}$ ) can arise on the surface of CNTs as the result of the applied synthesis and purification procedures. The step-like behavior was explained by presence of carbonyl functional groups and phenolic hydroxyls with $\mathrm{pK} \sim 2-3$ and 10, respectively. Therefore, the observed dependence $\zeta(\mathrm{pH})$ evidently reflected the contribution of functional groups on the surface of MWCNTs, and changes in the synthesis and purification procedures can result in changes of the shape of $\zeta(\mathrm{pH})$.

Figure $2 b$ shows the effects of electrolytes $\mathrm{KCl}, \mathrm{CaCl}_{2}$ and $\mathrm{AlCl}_{3}$ on the $\zeta$-potential of MWCNTs $(0.01 \% \mathrm{wt})$ in water [10]. Addition of a $\mathrm{KCl}$ solution resulted in an initial increase of the $\zeta$-potential and at high $\mathrm{KCl}$ concentrations (above $6.6 \cdot 10^{-3} \mathrm{~mol} / \mathrm{dm}^{3}$ ) a decrease of the $\zeta$-potential was observed. Such a dependence with a maximum at low ionic strength values can be attributed to surface conductivity effects [11]. Polarization of the EDL can induce the dipole moment oriented oppositely to the external electric field. The dipole moment magnitude increases with increasing the electrolyte content. 
This leads to an increasing retardation of the particle movement in the electric field. However, at high electrolyte concentrations, this effect is overcompensated by the EDL compression and this results in a decrease in mobility. Typically, appearance of unusual changes in the $\zeta(C)$ dependence corresponds to electrolyte concentrations at which contribution of the surface conductivity to the conductivity of dispersions is quite large. For bivalent $\left(\mathrm{CaCl}_{2}\right)$ and trivalent $\left(\mathrm{AlCl}_{3}\right)$ counter-ions increase in concentration, $C$, resulted in considerable decrease of the $\zeta$-potential of MWCNTs, moreover with adding of $\mathrm{AlCl}_{3}$ the overcharging of nanotubes above some critical concentration $\left(\approx 2 * 10^{-4} \mathrm{M}\right)$ was observed (Fig. $1 \mathrm{~b}$ ). Such behavior is rather typical for hydrophobic colloidal particles [11].

\section{REGULATION OF COLLOIDAL STABILITY}

To improve the dispersibility of carbon nanotubes, their colloidal stability and adsorptive properties (increase of their surface activity and specific surface area) several approaches have been proposed:

- stabilization in mixtures of water and organic solvents [12];

- functionalization by chemical treatment of the MWCNT surface [13];

- stabilization by additives of surfactants or polymers de-bundling the aggregated MWCNTs $[14,15]$;

- hybridization by addition of supplementary stabilizing nanoparticles (formation of hybrid MWCNT-based particles) [16].
Mixed solvents. The dispersibility of carbon nanotubes can be noticeably improved in nonaqueous solvents or mixtures of water with suitable organic solvent [12]. MWCNTs can be significantly debundled in ,good” solvents, such as 1-cyclohexyl-2-pyrrolidone (CHP), N,N-dimethylformamide (DMF), and N-methyl-2pyrrolidone (NMP) [12]. For example the aprotic CHP can disperse MWCNTs up to $3.5 \mathrm{mg} / \mathrm{mL}$ with very large populations of individual particles [12]. The dispersibility of carbon nanotubes in the given solvent is defined by the energetic costs of nanotube exfoliation. The "good" solvents have surface tension close to $\approx 40 \mathrm{~mJ} / \mathrm{m}^{2}$ [12], moreover, it was speculated that the dispersibility can be predicted from estimation of Hansen solubility parameter [17].

The dispersibility of MWCNTs in the mixture of CHP ("good") and water ("poor") solvents has been studied [18]. The CHP and water have significantly different total Hansen parameters: $\quad \delta_{T}=47.8 \mathrm{MPa}^{1 / 2} \quad$ and $\delta_{T}=20.5 \mathrm{MPa}^{1 / 2}$, respectively [17]. This difference is related to the differences in dispersion and hydrogen bonding components of the Hansen parameters for CHP and water. Nevertheless, the CHP is fully miscible with water below the lower consolute temperature $T \approx 320 \mathrm{~K}$ [19].

Fig. 2 shows examples of photos of nanotubes suspensions (for mass concentration of nanotubes $C_{n}=0.1 \% \mathrm{wt}$.) at two small and large mass fraction of water, $x_{w}$, in mixed solvent $\left(=m_{w} /\left(m_{w}+m_{C H P}\right)\right.$, where $m_{w}$ and $m_{C H P}$ are the masses of water and CHP, respectively) [18].

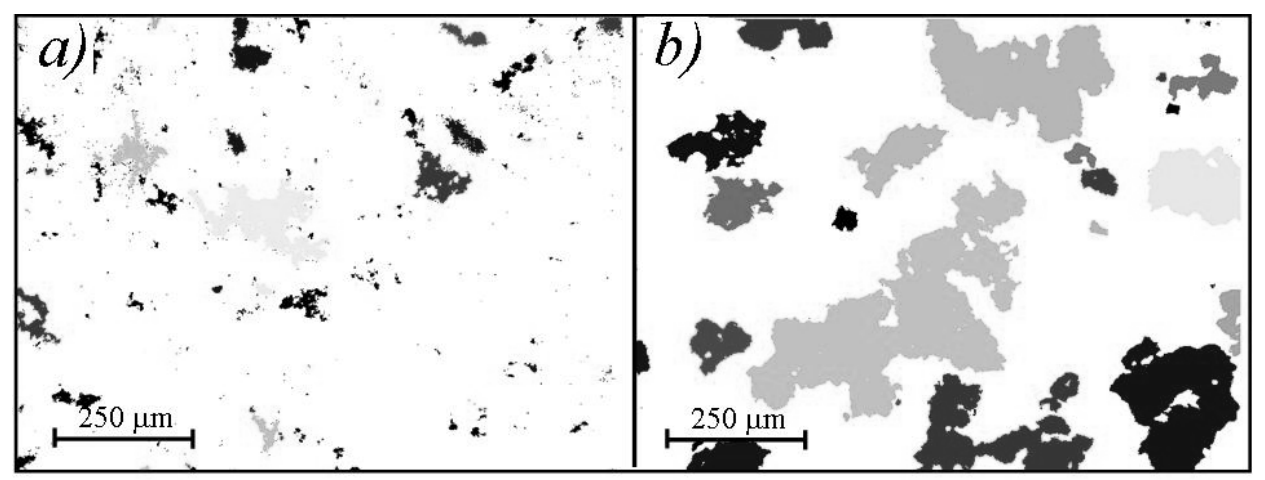

Fig. 2. Examples of optical microscopy images of $0.1 \% \mathrm{wt}$. MWCNT suspensions at different mass fractions of water, $x_{m}$, in mixed water + CHP solvents: $x_{w}=0.15(a)$ and $x_{w}=0.75(b)$. Different colors correspond to the different clusters. The temperature was $294 \mathrm{~K}$, and $x_{w}=m_{w} /\left(m_{w}+m_{C H P}\right)$, where $m_{w}$ and $m_{C H P}$ are the masses of water and CHP, respectively (adapted from [18]) 
The nanotubes clusters were not detected visually in pure CHP, but even at a low concentration of water $\left(x_{w}=0.05\right)$, they became visible and their size increased with an increase of the water content. For example, the mean radius of two-dimensional projections of clusters was about $25 \mu \mathrm{m}$ at $x_{w}=0.05$ and it was about $850 \mu \mathrm{m}$ at $x_{w}=1.0$ (pure water). Observed clusters were ramified, their surface was tortuous and fractal. The estimated fractal dimensionality of the aggregate surface increased with $x_{w}$.

The changes in the dispersibility of MWCNTs greatly affected the electrical conductivity of suspensions, $\sigma$, in mixed water + CHP solvents. Fig. 2 shows $\sigma$ versus the concentration of MWCNTs, $C_{n}$, at different mass fractions of water, $x_{m}$. [18]. Electrical conductivity significantly increased (by several orders of magnitude) even at rather small concentrations of nanotubes (below $1 \%$ ). This clearly evidenced the presence of percolation transition related to the bridging of different clusters. In absence of water $\left(x_{w}=0\right)$ the electrical conductivity was low and the percolation transition was rather smooth. The inset to Fig. 3 shows the value of $\sigma_{s}$ determined at fixed $C_{n}=1.0 \%$ wt. versus the value of $x_{w}$. The value of $\sigma_{s}$ significantly increased with $x_{w}$, and it was estimated that in the poor solvent (water) it is approximately 25 times higher than that in the good solvent (CHP). Such behavior in water can be explained by easier constant between large ramified clusters and improvement of electrical contacts between different nanotubes because of the appearance of hydrophobic attraction.

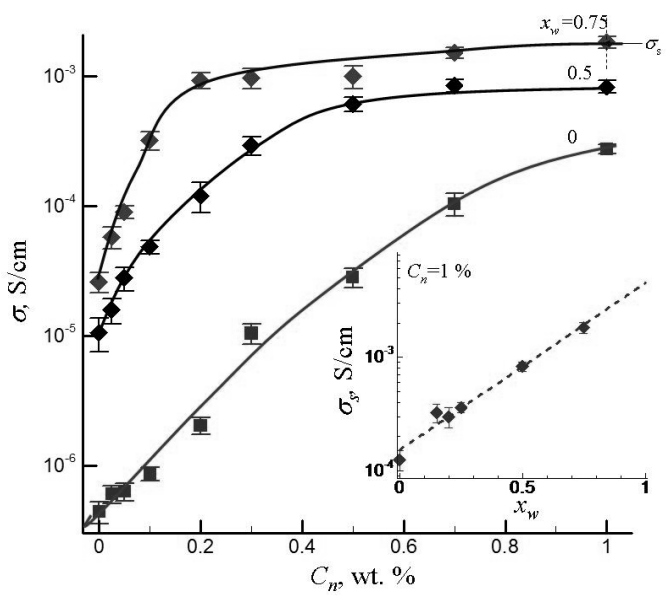

Fig. 3. Electrical conductivity $\sigma$ versus concentration of MWCNTs, $C_{n}$, in mixed water+CHP solvents at different mass fraction of water, $x_{m}$. Inset shows the value of electrical conductivity $\sigma_{s}$ at fixed $C_{n}=1.0 \%$ versus $x_{w}$. The temperature was $294 \mathrm{~K}$ (adapted from [18])

Functionalization of CNT surface. Colloid stability of aqueous suspensions can be improved by oxidation or functionalization of the MWCNTs [13]. The surface functional groups determine the wetting properties, surface charge density, and $\zeta$-potential of nanotubes. For example, oxidation of CNTs by acids, hydrogen peroxide, ozone, etc. can lead to formation of carboxyl, carbonyl and hydroxyl groups on the CNTs surface [20]. Correlation between $\zeta$ potential, dispersion in solvents and oxygen content of multi-walled CNTs, modified by functionalization, have been discussed [21]. The observed electrokinetic behavior of the CNTs was similar to that typical for hydrophobic colloids. MWCNTs modified with application of stabilization or chemical functionalization techniques were used for production of filtering sheets (so called, bucky-papers), and absorbing additives [22] for purification of water [23].

Adding of surfactants. Effect of different surfactants on stabilization of aqueous dispersion of CNTs has been discussed in the literature in detail $[14,15,24]$. It has been demonstrated that the dispersibility of carbon nanotubes is a complex function of the type of surfactant (cetyltrimethylammonium bromide (CTAB), sodium dodecyl sulfate, Triton X-100, etc.), its concentration and the surfactant/CNTs ratio [25].

Cationic surfactant CTAB was widely used for stabilization of carbon nanotubes in aqueous suspensions [26-30]. The CTAB molecule has 
length of $2.33 \mathrm{~nm}$, and its critical micelle concentration (CMC) in water is $\approx 1 \mathrm{mM}$ (0.0364\% wt).

Isotherm of adsorption of CTAB on the MWCNT surface and behavior of $\zeta$-potential in the presence of CTAB were investigated in a number of works [27-30]. The aggregation stability was quantified using photometric dispersion analyzer (PDA) in a flow system by the PDA aggregation ratio $R_{P D A}$ [31]. Fig. 2 presents examples of $\zeta$-potential and PDA aggregation ratio, $R_{P D A}$, versus concentration of $\mathrm{CTAB}, C_{s}$, in aqueous suspension of MWCNTs $\left(C_{n}=0.003 \%\right.$ wt. $)[29,30]$. A change in the

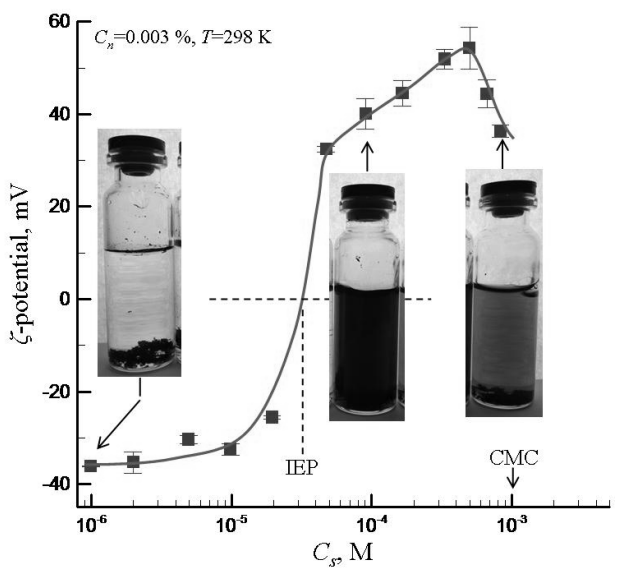

$a$ $\zeta$-potential from negative to positive values with increasing the CTAB concentration, $C_{s}$, was observed. The position of the isoelectric point (IEP) was found at about $C_{s}\left(\right.$ IEP) $\approx 3.7 \cdot 10^{-5} \mathrm{M}$. It corresponds to $0.51 \mathrm{mg}$ of $\mathrm{CTAB} / \mathrm{m}^{2}$ of the CNT surface $\left(x_{s}=m_{s} / m_{n}=0.13 \mathrm{~g} / \mathrm{g}\right)$. The decrease of $\zeta$-potential at larger concentrations of CTAB, above $C_{s}$ (IEP), was observed. This reflected the formation of $\mathrm{CTAB}$ micelles and their adsorption onto the MWCNT surfaces. The adsorption of surfactant micelles shifts the slip plane toward solution and decreases the $\zeta$-potential value.

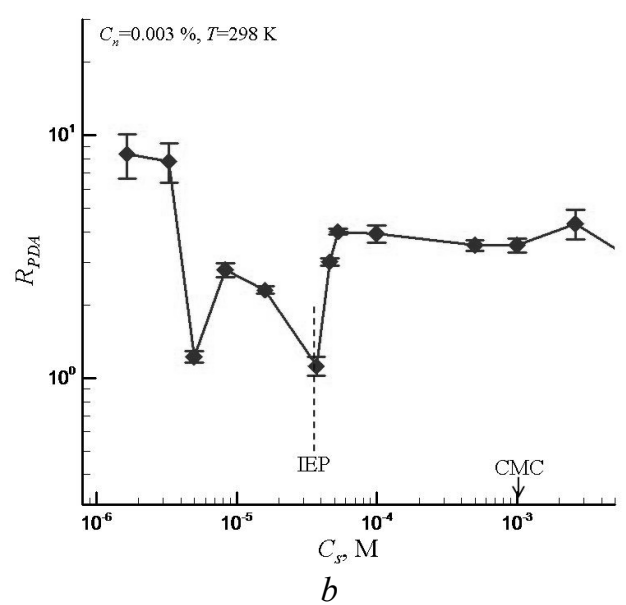

Fig. 4. $\zeta$-potential (a), and PDA aggregation ratio, $R_{P D A},(b)$ versus concentration of $\mathrm{CTAB}, C_{s}$, for aqueous suspensions of MWCNT $\left(C_{n}=0.003 \% \mathrm{wt}\right.$.) Insert to $(a)$ shows the sediment suspension photographs at $24 \mathrm{~h}$ after its preparation. The temperature was $298 \mathrm{~K}$ (adapted from [29, 30])

The similar overcharging behaviour was also observed in other works $[27,28]$. For example, for $0.175 \% \mathrm{wt}$. aqueous suspension of MWCNTs the position of the isoelectric point (IEP) was about $C_{s} \approx 1 \mathrm{mM}$ at $\mathrm{pH} 6.3$ and the zeta potential reached the saturation level of about $50 \mathrm{mV}$ for $C_{s} \geq 2 \mathrm{mM}$ [28].

Also the CTAB/MWCNTs ratio affects the character of adsorption and stabilization of nanotubes in aqueous suspensions [26]. For example, at $C_{s}=0.27 \mathrm{mM}$ (below CMC) the $\zeta$-potentials of nanotubes were negative $\left(\zeta=-46 \mathrm{mV}\right.$ at $C_{n}=10^{-3} \% \mathrm{wt}$, and $\zeta=-25 \mathrm{mV}$ at $\left.C_{n}=10^{-2} \% \mathrm{wt}.\right)$, whereas at $C_{s}=2.7 \mathrm{mM}$ (above CMC) they turned out to be positive ( $\zeta=66 \mathrm{mV}$ at $C_{n}=10^{-3} \% \mathrm{wt}$., and $\zeta=40 \mathrm{mV}$ at $C_{n}=10^{-2} \%$ wt.). For low concentration of MWCNTs, $\quad C_{n}=10^{-3} \% \mathrm{wt}$., the effective stabilization over a 15 -day period was observed for both $C_{s}=0.27 \mathrm{mM}$ (below CMC) and $C_{s}=2.7 \mathrm{mM}$ (above CMC). For high concentration of MWCNTs, $C_{n}=2.5 * 10^{-2} \%$, the stabilization was more efficient at $C_{s}=0.27 \mathrm{mM}$ than that at $C_{s}=2.7 \mathrm{mM}$. The observed phenomena were explained by differences in adsorption of individual CTAB molecules and worm-like CTAB micelles on the surface of nanotubes [26].

The dispersibility of carbon nanotubes in the presence of $\mathrm{CTAB}$ and aggregation stability of MWCNTs were studied in different works $[26,29,30,32]$. The optimum concentration of CTAB to achieve homogeneous dispersibility of carbon nanotubes in aqueous suspensions was identified to be near the CMC $[26,32]$. Remarkable that, in spite of the high negative charge of the carbon nanotubes, they were unstable in aqueous suspensions in the absence 
of CTAB $[29,30]$. At $C_{s}=0 \mathrm{M}$ the nanotubes at $C_{n}=0.003 \%$ formed large visible aggregates and the measured values of PDA ratio were rather large $(R \approx 8)$ (Fig. $4 b)$. However, addition of CTAB in the concentration interval between $5 \cdot 10^{-6}$ and $3.7 \cdot 10^{-5} \mathrm{M}$ resulted in stabilization of CNT suspension and the $R$ values diminished to 1.5-3.0. It is unusual that stabilization was observed even in the vicinity of the isoelectric point, i.e. at $C_{s}(\mathrm{IEP})=3.7 \cdot 10^{-5} \mathrm{M}$. At high CTAB concentrations, above the IEP (e.g., at CMC, $C_{s} \approx 1 \mathrm{mM}$ ), destabilisation and aggregation were again observed (Fig. 4). However, the character of this aggregation and aggregation at $C_{s}=0 \mathrm{M}$ were significantly different.

Fig. 5 shows examples of size distribution functions $V(d)$ in aqueous suspension of MWCNTs in the absence $\left(C_{s}=0 \mathrm{M}\right)$ and presence $\left(C_{s}=2.64 \mathrm{mM}\right)$ of CTAB [30]. The distribution functions were measured in gently stirred suspensions with applied hydrodynamic perturbations to prevent sedimentation of large aggregates. The distributions were monomodal and logarithmically symmetric without appearance of several fractions of nanotubes. In the absence of CTAB, the median size of aggregates was rather small, $d_{50} \approx 22.5 \mu \mathrm{m}$, and this size was roughly twofold higher than the maximum length of individual carbon nanotubes $(5-10 \mu \mathrm{m})$. These primary aggregates in the absence of $\mathrm{CTAB}$ are stable and resistant to the applied shear.

Addition of CTAB significantly modified the size distribution and a rather sharp transition from small primary aggregates to large secondary aggregates at concentrations above $C_{s}^{\mathrm{CMC}}$ was observed [30]. For example, the median size was $d_{50} \approx 154 \mu \mathrm{m}$ at $C_{s} \approx 2.64 \mathrm{mM}$ (Fig. 5). A oneweek aging of nanotube suspensions containing different amounts of $\mathrm{CTAB}$ (with $C_{s}$ between 0.001 and $5.2 \mathrm{mM}$ ), or supplementary ultrasonic treatment in the measuring unit after formation of initial aggregates (for $10 \mathrm{sec}-2 \mathrm{~min}$ ) did not significantly affected the stability of the systems neither in diluted (below $\mathrm{CMC}$ ) nor in concentrated (above CMC) systems.

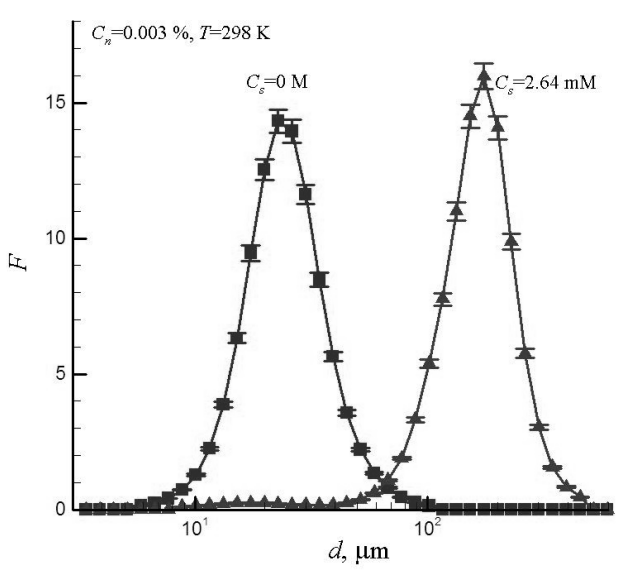

Fig. 5. Size distribution functions $F(d)$ in aqueous suspensions of MWCNTs in the absence and presence of CTAB. The aging time after ultrasonic pre-treatment time for $5 \mathrm{~min}$ was $2 \mathrm{~h}$. The temperature was $298 \mathrm{~K}$ (adapted from [30])

Different mechanisms responsible for stabilization of MWCNT suspensions in the presence of CTAB were identified (Fig. 6). At small values of $C_{s}$ (below IEP) the decorated adsorption of CTAB can be realized in the form of patches with different organization of CTAB molecules on the nanotube surface (Fig. $6 a$ ):

- the positively-charged groups of CTAB $\left[\mathrm{CH}_{3}\left(\mathrm{CH}_{2}\right)_{15}\left(\mathrm{CH}_{3}\right)_{3} \mathrm{~N}^{+}\right]$can neutralize the negatively charged surface groups. This results in the screening of nanotube charge and formation of hydrophobic patches around nanotubes.

- the long alkyl chain (length of $\sim 2 \mathrm{~nm}$ ) can be attracted toward the "pure" carbon skeleton by hydrophobic forces. This charges the nanotubes positively and results in formation of hydrophilic shells around nanotubes.

The observed effect of CTAB induced stabilization of aqueous suspension of CNTs can 
reflect competition between these two adsorption mechanisms. Note that structural repulsion forces can originate between the layers of adsorbed strongly hydrated CTAB molecules. In the vicinity of $\mathrm{CMC}$ the differences in adsorption of individual $\mathrm{CTAB}$ molecules and worm-like CTAB micelles on the CNT surface may be also important $[27,28]$. At concentrations of CTAB

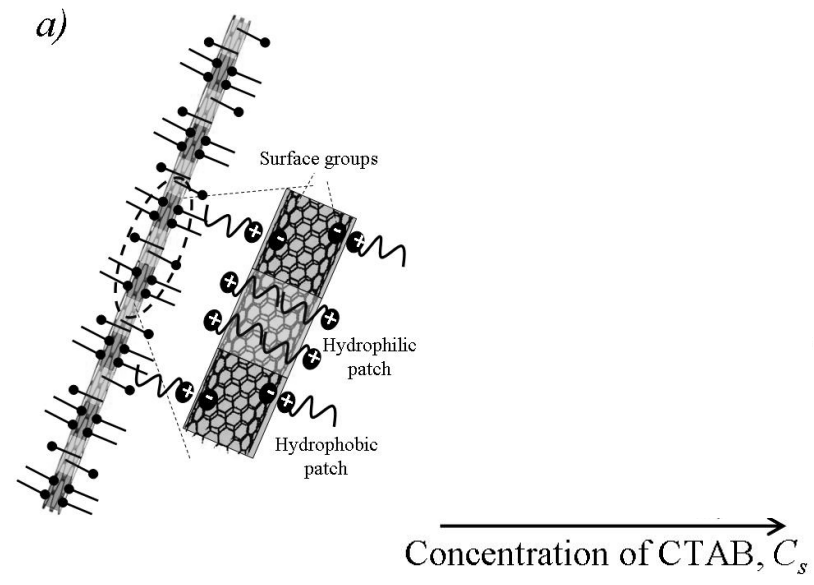

above IEP more complex mechanisms of adsorption of individual CTAB molecules and micelles/semi-micelles on the hydrophobic surface might be realized [33]. The different types of encapsulation of nanotubes in a cylindrical surfactant micelle, hemi-micellar adsorption and random adsorption can be also considered (Fig. $6 b$ ).

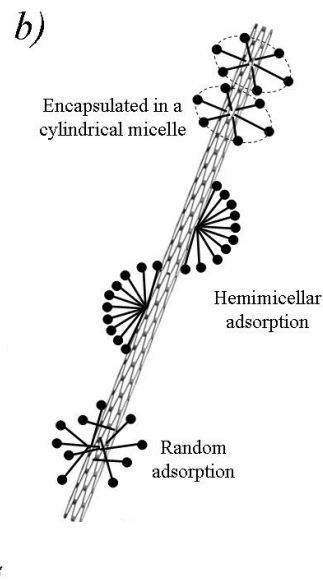

Fig. 6. Adsorption mechanisms of $\mathrm{CTAB}$ on the surface of carbon nanotubes at low $(a)$ and large $(b)$ concentration of CTAB (with permission from [29])

Hybridization with other nanoparticles. Hybridization with other nanoparticles has attracted a great attention during the last decades [34-36]. In this technique the MWCNTs are used as a base for preparation of hybrid particles with superior chemical activity, surface area and adsorptive properties as compared to intact MWCNTs. Different methods were proposed for preparation of hybrids: covalent and noncovalent interaction, in situ sol-gel process, chemical vapor deposition, electrochemical deposition, etc. [37].

Recently, a new type of hybrid based on MWCNTs covered by platelets of Laponite $\mathrm{RD}{ }^{\circledR}$ (Lap) was described [16]. Lap represents a synthetic clay with the formula of $\mathrm{Na}_{0.7}\left[\left(\mathrm{Si}_{8} \mathrm{Mg}_{5.5} \mathrm{Li}_{0.4}\right) \mathrm{O}_{20}(\mathrm{OH})_{4}\right]$, and it is composed of charged platelets with thickness of about $1 \mathrm{~nm}$ and average diameter of about 25-30 $\mathrm{nm}$. The negative surface charge of Lap faces is counterbalanced by the positive charge of exchangeable sodium ions (for other details, see the recent review [38]). Adhesion of charged Lap nanoparticles on the surface of nanotubes improved their dispersion [10, 29, 39-44]. Addition of Lap resulted in efficient dispersion of MWCNT aggregates and separation of individual nanotubes (Fig. 7). In the presence of optimal concentration of Laponite $\left(x_{l} \approx 0.3\right)$, all nanotube particles got stabilized, and a step-wise increase of sedimentation stability was observed [16]. Stabilization of nanotubes by Lap nanoparticles was explained by formation of the hydrophilic charged shells on the nanotube surface. The presence of Lap shells around the MWCNT surface was recently visualized using high resolution TEM technique [43].

Fig. 8 a illustrates the effect of Lap additions on the $\zeta$-potential of MWCNT + Lap hybrids. An increase in $x_{l}=m_{l} / m_{n}$ ratio (here $m_{l}$ and $m_{n}$ are the masses of Lap and MWCNTs, respectively) from 0 to 0.4 resulted in a monotonic decrease of $\zeta$-potential from -40 to $-32 \mathrm{mV}$. The $\zeta$-potential reached plateau value $\approx-32 \mathrm{mV}$ at $x_{l} \geq 0.4$ that corresponds to the $\zeta$-potential of "pure" Lap platelets, $\zeta \approx-30 \mathrm{mV}$ [10], i.e. the MWCNT + Lap hybrids acquired the $\zeta$-potential of the "pure" Lap platelets. Such behaviour evidenced the high surface coverage of nanotubes surface with Lap at $x_{l} \geq 0.4$.

The observed heterocoagulation and formation of MWCNT + Lap hybrids reflect the presence of attractive interactions between similarly charged species. Such attractive forces 
can exist between similarly and highly charged colloidal particles (see [45] for a review). The charge non-uniformity on the surface of MWCNTs (see e.g., Fig. 6) may significantly contribute to the attractive interactions. The Lap disks can be effectively immobilized on the neutral parts of the nanotube surface due to strong attractive electrostatic image forces between the charged particles and neutral graphite-like surface. The examination of size distribution function of MWCNT + Lap hybrids revealed the presence of species with different sizes (Fig. $8 \mathrm{~b}$ ). At small content of Lap $\left(x_{l}=0.1\right)$, the relatively large aggregates of nonstabilized nanotubes (several $\mu \mathrm{m}$ ), intermediate aggregates of partially stabilized nanotubes $(300-1000 \mathrm{~nm})$ and small species of stabilized hybrids (100-200 nm) were observed. Note that even at small content of Lap the size of particles was significantly smaller than that in absence of Lap (Fig. 5). At higher concentrations of Lap $\left(x_{l}=0.6\right.$ and $\left.x_{l}=0.7\right)$ the content of the partially stabilized and stabilized hybrids was noticeably higher.

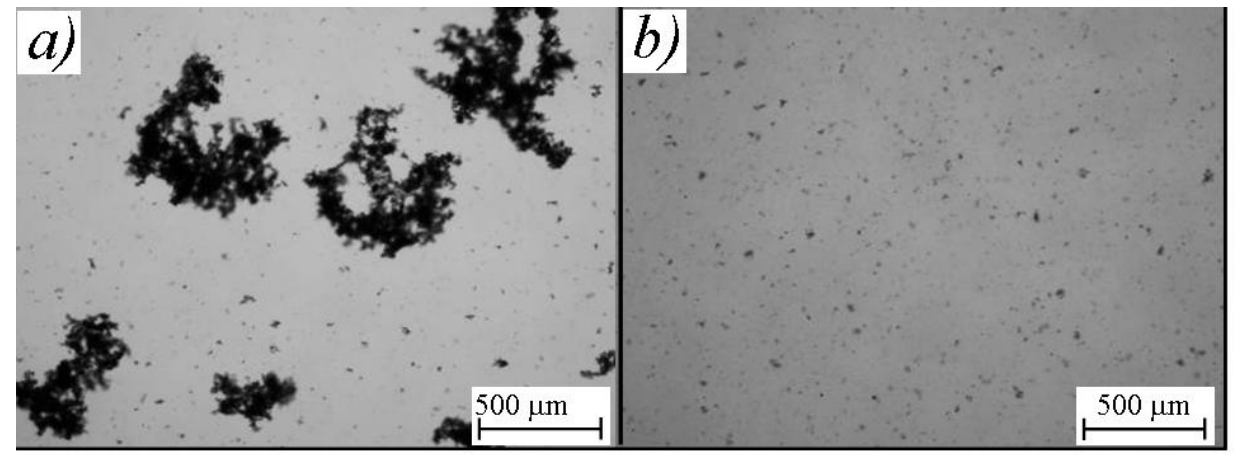

Fig. 7. Examples of optical microscopy images of $0.01 \%$ MWCNT aqueous suspensions at different ratios Lap and MWCNT: $x_{l}=0.0(a)$ and $x_{l}=0.2(b)$. Here $x_{l}=m_{l} / m_{n}$, where $m_{l}$ and $m_{n}$ are the masses of Lap and MWCNTs, respectively. The temperature was $298 \mathrm{~K}$ (adapted from [16])
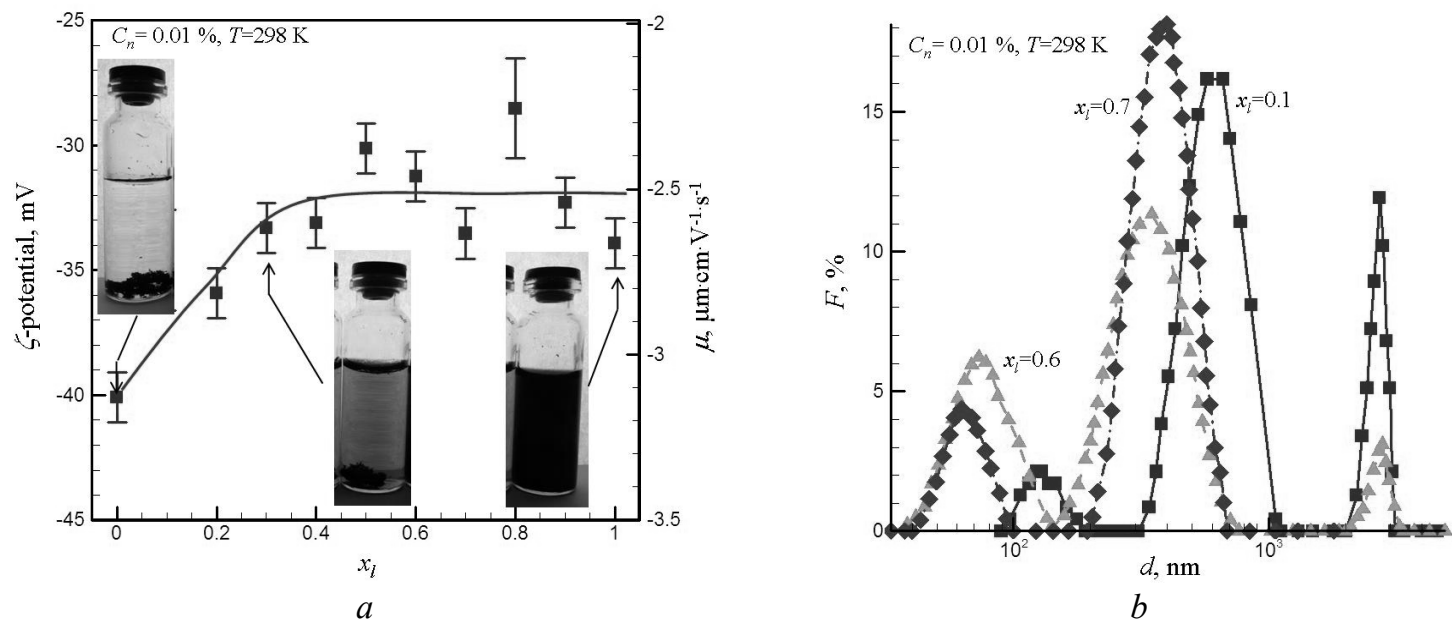

Fig. 8. $\zeta$-potential (the electrophoretic mobility $\mu$ at right axes) of MWCNTs+Lap hybrids in water versus ratio Lap and MWCNT, $x_{l},(a)$, and size distribution functions $F(d)$ at different values of $x_{l}$. Here $x_{l}=m_{l} / m_{n}$, where $m_{l}$ and $m_{n}$ are the masses of Lap and MWCNTs, respectively. The aging time after ultrasonic pre-treatment time for 5 min was $2 \mathrm{~h}$, the temperature was $298 \mathrm{~K}$ (adapted from [10]) 


\section{ADSORPTIVE PROPERTIES OF CNTS}

Adsorptive properties of carbon nanotubes are determined by their high specific surface area and functional groups on the surface. Typically they have cylindrical shape and consist of graphene sheets wrapped around themselves. The multi-wall carbon nanotubes (MWCNTs) contain two or more concentric shells with intershell distance $d_{s s}=0.34 \mathrm{~nm}$. For known outer diameter, $d_{o}$, and number of walls, $n$, of MWCNTs (of order 10-20 nm) the inner diameter $d_{i}$ can be evaluated as $d_{i}=d_{o}-2 n d_{s s}$. The mass of one nanotube with length of $L$ (of order
5-10 $\mu \mathrm{m})$ can be evaluated as $m_{n}=\pi L d_{0} n(1-$ $\left.(n+1) d_{s s} / d_{0}\right) / S_{c}$ where $S_{c}\left(\approx 1315 \mathrm{~m}^{2} / \mathrm{g}\right)$ is the surface area of the graphene sheet $[46,47]$. Then the specific surface area can be evaluated as [10]:

$S=s_{n} / m_{n}=S_{c} /\left[n\left(1-(n+1) d_{s s} / d_{0}\right]\right.$,

where $s_{n}=\pi L d_{0}$ is the surface of one nanotube.

Fig. 9 presents evaluated specific surface area, $S$, versus the external diameter of MWCNTs, $d_{0}$, at different values of $n$. Note that increase of the number of walls, $n$, or the outer diameter, $d_{0}$, results in decrease of the value of $S$.

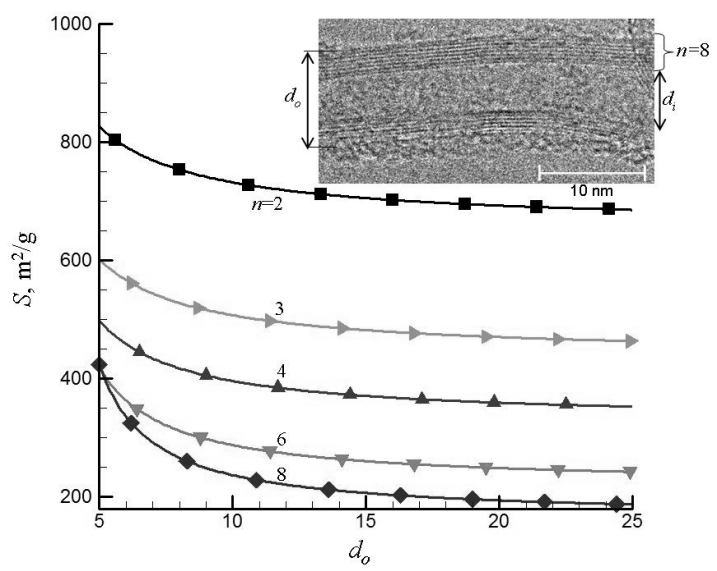

Fig. 9. Calculated specific surface area of MWCNTs, $S$, (Eq. (2) versus its outer diameter, $d_{0}$, at different numbers of walls, $n$. Inset shows example of TEM image of MWCNTs (adapted from [10])

Recent studies have shown the good potential of MWCNTs for adsorptive purification of water contaminated by toxic metals [48], organic matters [49], and synthetic dyes [50].

The specific surface area of CNTs can be experimentally estimated using the gas adsorption isotherm (e.g., $\mathrm{N}_{2}$ ), or dye adsorption from the liquid phase. The methylene blue (MB) is frequently used as a model dye in investigations of adsorption on carbon-based substances. The kinetic and equilibrium data for adsorption of MB on MWCNTs at different temperatures have been analyzed [51]. Adsorption equilibrium was attained within $\approx 2 \mathrm{~h}$ and the estimated thermodynamic parameters suggested that adsorption was spontaneous and endothermic. Adsorption was rapid in the initial stage and then followed by a slower process to reach the plateau value [52]. Based on the studies of adsorption of MB on SWCNTs, it was concluded that adsorption is controlled by charge-transfer and hydrophobic interactions [53]. From studies of adsorption of MB on MWCNTs at different $\mathrm{pH}$ it was speculated that the adsorption mechanism may be due to $\pi-\pi$ electron donor acceptor interactions and electrostatic attraction between positively charged dye ions and nanotubes [54].

The alkali-activated nanotubes demonstrated excellent adsorption capacity of MB [55]. The effects were attributed to the multiple adsorption interaction mechanisms on the functionalized surface (hydrogen bonding, $\pi-\pi$ and electrostatic interactions, etc.). The adsorption capacity of MB on modified nanotubes increased after heat treatment, and decreased after acid modification [56]. The method of removal of MB from aqueous solution using magnetic MWCNTs was proposed $[57,58]$. Magnetic nanotubes can be easily separated in magnetic field after they have been loaded with dye. The MWCNT-based 
hybrid sorbents can be used for water purification from different inorganic, organic and biological compounds, and nanoparticles [34-36].

MWCNT + Lap hybrids can be also effectively used for removal of MB from aqueous systems. Adsorption of $\mathrm{MB}$ on MWCNT + Lap and dead-end membrane have been studied $[42,44]$. The size and the shape of hybrid particles were determined by nanotubes, whereas the adsorption properties were determined by Lap particles attached to the surface of nanotubes. Due to the presence of Lap, the adsorbing capacity of hybrid was much higher as compared to the adsorbing capacity of pure nanotubes.

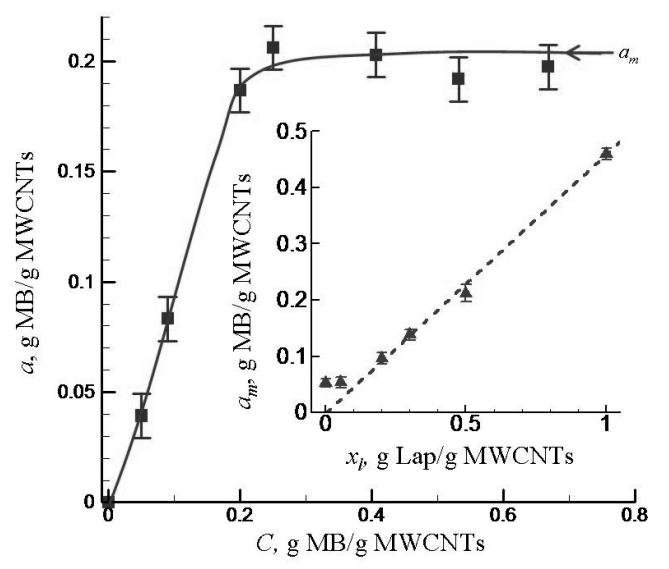

Fig. 10. Adsorption curve of MB on MWCNT + Lap hybrid $\left(x_{l}=0.5\right)$ represented as the relative quantity of the $\mathrm{MB}$ adsorbed by hybrid, $a$, versus the MB/MWCNTs ratio in suspension, $C_{d}$. Inset shows the saturation value $a_{m}$ versus the ratio $x_{l}=m_{l} / m_{n}$, where $m_{l}$ and $m_{n}$ are the masses of Lap and MWCNTs, respectively. Duration of adsorption time was $3 \mathrm{~h}$, the temperature was $298 \mathrm{~K}$ (adapted from [42])

Fig. 10 presents example of adsorption curve of MB on MWCNT + Lap hybrid $\left(x_{l}=0.5\right)$ represented as the relative quantity of the $\mathrm{MB}$ adsorbed by hybrid, $a$, versus the MB/MWCNTs ratio in suspension, $C_{d}$. For $C_{d}<0.2$ (low $\mathrm{MB} / \mathrm{MWCNTs}$ ratio) the purified solution was practically colourless, which is the evidence of complete adsorption of the MB. The adsorption reached its saturation level, $a_{m}$, at a certain critical MB/MWCNTs ratio $\left(C_{d} \geq 0.2\right)$, and remained constant with the further increase of the MB concentration (Fig. 10). Inset to Fig. 10 presents the saturation adsorption of the MB, $a_{m}$, at different values of $x_{l}$. The maximal adsorption of the MB in suspensions of pure MWCNTs (at $x_{l}=0$ ) was relatively low, $a_{m}=0.053 \pm 0.007 \mathrm{~g}$ $\mathrm{MB} / \mathrm{g}$ MWCNTs. The increase of $x_{l}$ resulted in increase of $a_{m}$ and at $x_{l}=0.2-1$, the direct proportionality between $a_{m}$ and $x_{l}$ was approximately observed, $a_{m} \approx 0.46 x_{l}$.

The MWCNT + Lap hybrids may be used either as a purifying additive or as a filtering layer if it is deposited on the surface of a supporting membrane. Due to relatively large size of hybrid particles, they can be easily separated from the purified solution by filtration or centrifugation. Figure 11 shows the hybrid membrane, obtained by filtration of hybrid MWCNT + Lap suspension $\left(x_{l}=0.5\right)$ through the nylon membrane with nominal pore size $0.2 \mu \mathrm{m}$ (a), and ESEM image of the dynamic layer of MWCNT + Lap hybrids [42].

The dynamic homogeneous layers of hybrids have a micro-porous felt-like structure with a carcass composed of disaggregated MWCNTs. The average pore size of the layer, formed by hybrids, was rather small $(<1 \mu \mathrm{m})$. The estimated specific filtration resistance of hybrids increased from $2.0 \cdot 10^{12} \mathrm{~m} / \mathrm{kg}$ to $7.1 \cdot 10^{13} \mathrm{~m} / \mathrm{kg}$ with increase of $x_{l}$ from 0 to 0.5 . For comparison, the specific filtration resistance of pure Lap was much high $1.5 \cdot 10^{15} \mathrm{~m} / \mathrm{kg}$.

The kinetics of adsorption and parameters of equilibrium adsorption of MB on MWCNT + Lap hybrids have been also investigated in detail [44]. For elucidation of the mechanism of MB adsorption, the electrical conductivity and $\zeta$-potential were measured [42,44]. Three different stages in the kinetics of adsorption were observed: a fast initial stage I $(t=0-10 \mathrm{~min})$, a 
slower intermediate stage II (up to $t \approx 120 \mathrm{~min}$ ) and a long-lasting final stage III (up to $t \approx 24 \mathrm{~h}$ ). The presence of these stages was explained accounting for different types of interactions between MB and hybrids, as well as for the changes in the structure of aggregates and the long-range restructuring of Lap platelets on the surface of MWCNTs. The analysis of the adsorption data of MB by MWCNT + Lap hybrid particles evidenced in favor of the model with linear contacts between rigid Lap platelets and MWCNTs [44].

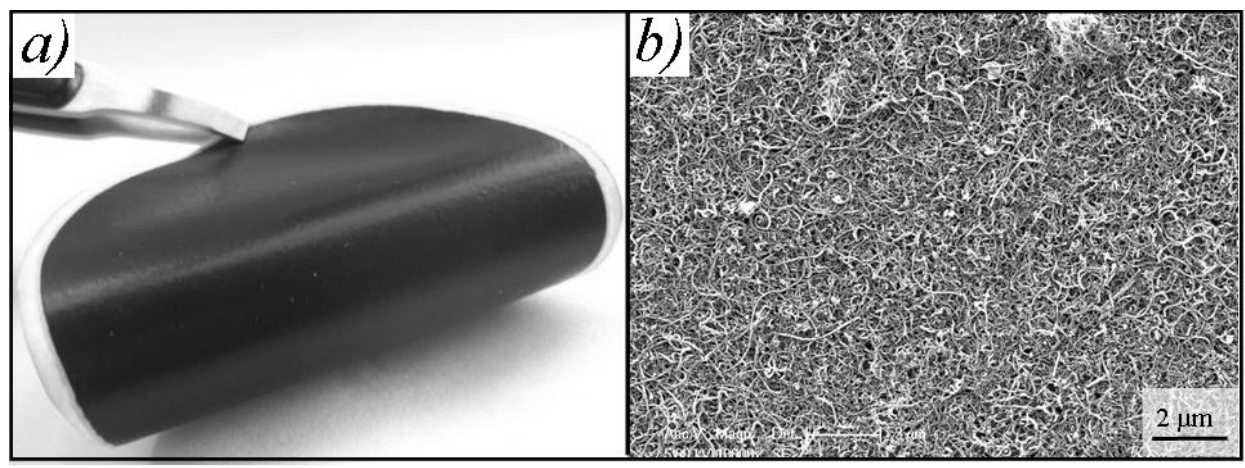

Fig. 11. Hybrid membrane, obtained by filtration of hybrid MWCNT + Lap suspension $\left(x_{l}=0.5\right)$ through the nylon membrane with nominal pore size $0.2 \mu \mathrm{m}(a)$, and ESEM image of the dynamic layer of MWCNT + Lap hybrids (adapted from $[42,59])$

\section{ACKNOWLEDGEMENTS}

This work was partially funded by the NAS of Ukraine under Project 2.16.1.4 and it was performed in the frame of bilateral cooperation agreement between Hungarian and Ukrainian Academies of Sciences. Also the research in part was carried out in the framework of the GINOP2.3.2-15-2016-00010 "Development of enhanced engineering methods with the aim at utilization of subterranean energy resources" project of the Research Institute of Applied Earth Sciences of the University of Miskolc in the framework of the Széchenyi 2020 Plan, funded by the European Union, co-financed by the European Structural and Investment Funds.

\title{
Короткий огляд про регулювання стабільності водних суспензій вуглецевих нанотрубок
}

\author{
М.В. Маніло, М.І.Лебовка, Ш. Барані \\ Інститут біоколоїдної хімії ім. Ф.Д. Овчаренка Національної академії наук України \\ бул. Вернадського, 42, Київ, 03142, Україна, lebovka@gтаil.com \\ Університет Мішкольи, Науково-дослідний інститут прикладних наук про Землю та дослідницька група з \\ матеріалів із матеріалознавства MTA-ME, Угорщчина, akmbsab@uni-miskolc.hu
}

У изьому огляді аналізуються нещодавні роботи авторів та споріднені роботи щуодо електрокінетичних властивостей та колоїдної стійкості водних суспензій багатошарових вуглечевих нанотрубок (CNTs) у присутності поверхнево-активних речовин (ПАР) та наночастинок. Дано розгляд також адсорбиійних властивостей вуглецевих нанотрубок.

Обговорюється застосування класичних теорій електрофорезу для опису електрофоретичної рухливості вуглецевих нанотрубок. Наведено приклади Г-потенціалу CNTs у водних суспензіях як функції рН та концентрації електролітів ( $\left.\mathrm{KCl}, \mathrm{CaCl}_{2} \mathrm{ma} \mathrm{AlCl}_{3}\right)$. Додавання катіонної поверхнево-активної речовини изетилтриметиламмонію броміду (СТАВ) нижче значень критичної концентрачії міцелоутворення (СМС) призводить до зменшення, а потім до перезарядження поверхні CNTs шляхом накопичення іонів СTAB в шарі Штерна. При концентраціях вище СМС спостерігається значне спадання Ц-потенціалу. Це пов'язано зі 
змішенням площини зсуву в бік розчину в результаті утворення на поверхні напівміцел. Збільшення масового співвідношення штучного мінералу Лапоніт (Lap) у суспензї (X) від 0 до 0.4 призводить до монотонного

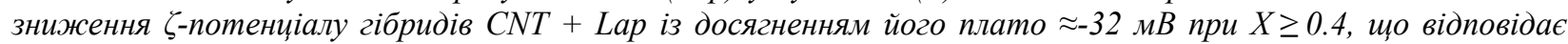

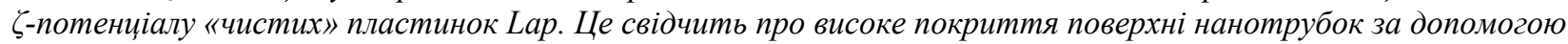
Lap при $X \geq 0,4$.

Коротко обговорюються основні методи поліпшення диспергованості вуглецевих нанотрубок, їхня колоїдна стійкість та адсорбиійні властивості, а саме: стабілізація в сумімах води та органічних розчинників; функціоналізація хімічною обробкою; стабілізація добавками поверхнево-активної речовини або полімерів та гібридизаџія шляхом додавання додаткових стабілізуючих наночастинок. CNTs можуть бути значно відокремлені в «гарних» розчинниках, таких як 1-циклогексил-2-піролідон, N,N-диметилформамід або N-метил-2-піролідон. Продемонстровано, щуо диспергованість CNTs є складною функиією типу ПАР, його концентрації та співвідношення ПАР/CNTs. Оптимальна концентрація СТАВ для досягнення однорідної водної дисперсії вуглецевих нанотрубок була визначена поблизу СМС. Додавання СТАВ значно модифікують розподіл за розмірами CNTs i спостерігається різкий перехід від малих первинних агрегатів до великих вторинних агрегатів при концентраціях вище СМС. При оптимальній концентрації Lар частинки нанотрубок добре стабілізуються $і$ спостерігається ступінчасте підвищення стабільності осадження. Ми також показали, щзо гібриди CNTs + Lap можуть ефективно використовуватися для видалення барвника метиленового синього з водних систем. Висвітлено кінетику та механізми адсорбиї.

Ключові слова: вуглеиеві нанотрубки, водяна суспензія, колоїдна стабільність, поверхнево-активні речовини, гібриди

\title{
Краткий обзор по регулированию стабильности водных суспензий углеродных нанотрубок
}

\author{
М.В. Манило, Н.И. Лебовка, Ш. Барани
}

Институт биоколлоидной химии им. Ф.Д. Овчаренко Национальной академии наук Украины бул. Вернадского, 42, Киев, 03142, Украина, lebovka@gmail.com

Университет Мишкольи, Научно-исследовательский институт прикладньх наук о Земле и исследовательская группа из материалов по материаловедению МТA-ME, Венгрия, akmbsab@uni-miskolc.hu

В этом обзоре анализируются недавние работы авторов и близкие работы по электрокинетических свойствам и коллоидной утойчивости водных суспензий многослойных углеродных нанотрубок (CNTs) в присутствии поверхностно-активные веществ (ПАВ) и наночастиц. Дано рассмотрение также адсорбичионных свойств углеродных нанотрубок.

Обсуждается применение классических теорий электрофореза для описания электрофоретической подвижности углеродных нанотрубок. Приведены примеры б-потенциала CNTs в водных суспензиях как функция $\mathrm{pH}$ и концентраџии электролитов ( $\mathrm{KCl}, \mathrm{CaCl}_{2}$ и $\left.\mathrm{AlCl}_{3}\right)$. Добавление катионной поверхностноактивного вещества иетилтриметиламмония бромида (СТАВ) ниже значений критической концентрации мицеллообразования (СМC) приводит к уменьшению, а затем к перезарядке поверхности CNTs путем накопления ионов СТАВ в слое Штерна. При конщентрациях выше СМС наблюдается значительное падение

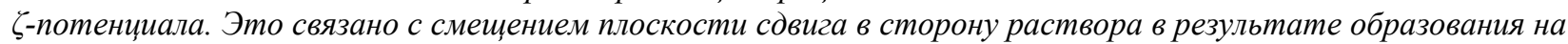
поверхности полумицелл. Увеличение массового соотношения искусственного минерала Лапонит (Lap) 8 суспензии $(X)$ от 0 до 0.4 приводит к монотонному снижению б-потенщиала гибридов УНТ + Лап $c$ достижением плато $\approx-32 \mathrm{MB}$ при $X \geq 0.4$, что соответствует $\zeta$ «истых» пластинок Lар. Это свидетельствует о высоком покрытия поверхности нанотрубок с помощьюю Lар при X $\geq 0.4$.

Коротко обсуждаются основные методы улучшения диспергованости углеродных нанотрубок, их коллоидная устойчивость и адсорбционнье свойства, а именно: стабилизация в смесях воды и органических растворителей; функционализачия химической обработкой; стабилизачия добавками поверхностноактивного вещества или полимеров и гибридизация путем добавления дополнительных стабилизирующих наночастиц. CNTs могут быть значительно отделены в «хороших» растворителях, таких как 1-циклогексил-2-пирролидон, $N$, N-диметилформамид или N-метил-2-пирролидон. Продемонстрировано, что диспергируемые CNTs является сложной функичей типа ЮАР, его концентрации и соотношения ЮAP/CNTs. Оптимальная концентраџия СТАВ для достижения однородной водной дисперсии углеродных 
нанотрубок была определена вблизи СМС. Добавление СТАВ значительно модифицируют распределение по размерам CNTs и наблюдается резкий переход от малых первичных агрегатов к большим вторичныл агрегатам при концентрациях выще CMC. При оптимальной концентрации Lар частиць нанотрубок хорошо стабилизируются и наблюдается ступенчатое повышение стабильности осаждения.

Mbl также показали, что гибриды CNTs + Lap могут эффективно использоваться для удаления красителя метиленового синего из водных систем. Освещеены кинетика и механизмы адсорбции.

Ключевые слова: углеродные нанотрубки, водные суспензии, коллоидная стойкость, зета-потенциал, поверхностно-активные вещества, гибриды

\section{REFERENCES}

1. Vakhrushev A.V., Kodolov V.I., Haghi A.K., Ameta S.C. Carbon Nanotubes and Nanoparticles: Current and Potential Applications. (Apple Academic Press, 2019).

2. Al-Hamadani Y.A.J., Chu K.H., Son A., Heo J., Her N., Jang M., Park Ch.M., Yoon Y.Stabilization and dispersion of carbon nanomaterials in aqueous solutions: A review. Sep. Purif. Technol. 2015. 156(2): 861.

3. Hunter R.J. Zeta potential in colloid science: principles and applications. (Academic press, 2013).

4. Besra L., Liu M. A review on fundamentals and applications of electrophoretic deposition (EPD). Prog. Mater. Sci. 2007. 52(1): 1 .

5. Kunz W. Specific Ion Effects, Evidences. In: Encyclopedia of Applied Electrochemistry. (Springer, 2014). P. 2045.

6. Lyklema J. Simple Hofmeister series. Chem. Phys. Lett. 2009. 467(4-6): 217.

7. Kim J.Y., Yoon B.J. Electrophoresis Theory of Nonspherical Particles. In: Interfacial Electrokinetics and Electrophoresis (Surfactant Science). (Marcel Dekker, Inc., 2002). P. 173.

8. Dukhin S.S. Non-equilibrium electric surface phenomena. Adv. Colloid Interface Sci. 1993. $44: 1$.

9. Chen Sh., Hu Sh., Smith E.F., Ruenraroengsak P., Thorley A.J., Menzel R., Goode, A.E. Ryan M.P., Tetley T.D., Porter A.E., Shaffer M.S.P. Aqueous cationic, anionic and non-ionic multi-walled carbon nanotubes, functionalised with minimal framework damage, for biomedical application. Biomaterials. 2014. 35(17): 4729.

10. Manilo M., Lebovka N., Barany S. Characterization of the electric double layers of multi-walled carbon nanotubes, laponite and nanotube+laponite hybrids in aqueous suspensions. Colloids Surf. A. 2014. 462: 211.

11. Barany S. Complex electrosurface investigations of dispersed microphases. Adv. Colloid Interface Sci. 1998. 75(1): 45.

12. Hughes J.M., Aherne D., Bergin Sh.D., O'Neill A., Streich P.V., Hamilton J.P., Coleman J.N. Using solution thermodynamics to describe the dispersion of rod-like solutes: application to dispersions of carbon nanotubes in organic solvents. Nanotechnology. 2012. 23(26): 265604.

13. Oh W.-C., Ko W.-B., Zhang F.-J. The functionalization and preparation methods of carbon nanotube-polymer composites: A review. Elastomers and Composites. 2010. 45: 80.

14. Lisunova M.O., Lebovka N.I., Melezhyk O.V., Boiko Y.P. Stability of the aqueous suspensions of nanotubes in the presence of nonionic surfactant. J. Colloid Interface Sci. 2006. 299: 740.

15. Clark M.D., Subramanian S., Krishnamoorti R. Understanding surfactant aided aqueous dispersion of multiwalled carbon nanotubes. J Colloid Interface Sci. 2011. 354(1): 144.

16. Loginov M., Lebovka N., Vorobiev E. Laponite assisted dispersion of carbon nanotubes in water. J. Colloid Interface Sci. 2012. 365(1): 127.

17. Hansen C.M. Hansen solubility parameters-A user's handbook. (Boca Raton, FL: CRC Press, 2007).

18. Deriabina O., Lebovka N., Bulavin L., Goncharuk A. Regulation of dispersion of carbon nanotubes in binary water+ 1-Cyclohexyl-2-pyrrolidone mixtures. Physica E Low-dimensional Systems and Nanostructures. 2014. 59: 150.

19. Lou A., Pethica B.A., Somasundaran P., Yu X. Phase behavior of N-Alkyl-2-pyrrolidones in aqueous and nonaqueous systems and the effect of additives. J. Colloid Interface Sci. 2002. 256(1): 190.

20. Datsyuk V., Kalyva M., Papagelis K., Parthenios J., Tasis D., Siokou A., Kallitsis I., Galiotis C. Chemical oxidation of multiwalled carbon nanotubes. Carbon. 2008. 46(6): 833.

21. Barany S., Kartel N., Meszaros R. Electrokinetic potential of multi-walled carbon nanotube in aqeous suspension of electrolytes and surfactants. Colloid J. 2014. 76(5): 509.

22. Brady-Estévez A.S., Schnoor M.H., Kang S., Elimelech M. SWNT-MWNT hybrid filter attains high viral removal and bacterial inactivation. Langmuir. 2010. 26(24): 19153. 
23. Thai O.Y., Latif A.A., Sharif Z.Sh.H., Huat T.S. A review on carbon nanotubes in an environmental protection and green engineering perspective. Braz. J. Chem. Eng. 2010. 27(2): 227.

24. Meng S.H., Yan J., Li H.G., Du S.G. The Effect of Surfactants on the Dispersion of Carbon Nanotubes in Water. Adv. Mater. Res. 2015. 1081: 142.

25. Lin L., Peng H., Ding G. Dispersion stability of multi-walled carbon nanotubes in refrigerant with addition of surfactant. Appl. Therm. Eng. 2015. 91: 163.

26. Devre R.D., Budhlall B.M., Barry C.F. Enhancing the Colloidal Stability and Electrical Conductivity of SingleWalled Carbon Nanotubes Dispersed in Water. Macromol. Chem. Phys. 2016. 217(5): 683.

27. Xiao Q., Wang P.-H., Ji L.-L. Dispersion of carbon nanotubes in aqueous solution with cationic surfactant CTAB. J. Inorg. Mater. 2007. 22(6): 1122.

28. De la Cruz E.F., Zheng Y., Torres E., Li W. Zeta potential of modified multi-walled carbon nanotubes in presence of poly (vinyl alcohol) hydrogel. Int. J. Electrochem. Sci. 2012. 7(4): 3577.

29. Manilo M.V., Lebovka N., Barany S. Combined effect of cetyltrimethylammonium bromide and laponite platelets on colloidal stability of carbon nanotubes in aqueous suspensions. J. Mol. Liq. 2017. 235 : 104.

30. Manilo M., Bohacs K., Lebovka N., Barany S. Impact of surfactant and clay platelets on electrokinetic potential and size distribution in carbon nanotubes aqueous suspensions. Colloids Surf. A. 2018. 544: 205.

31. Barany S., Gregory J. Flocculation of kaolin suspension by cationic polyelectrolites. Colloid J. 1996. $58(1)$ : 13.

32. Shin J.-Y., Premkumar T., Geckeler K.E. Dispersion of Single-Walled Carbon Nanotubes by Using Surfactants: Are the Type and Concentration Important? Chem. Eur. J. 2008. 14(20): 6044.

33. Koganovskii A.M., Klimenko N.A. Physical and chemical basis of removing the surfactant from aqueous solution and waste water. (Kyiv: Naukova dumka, 1978).

34. Addo Ntim S., Mitra S. Adsorption of arsenic on multiwall carbon nanotube-zirconia nanohybrid for potential drinking water purification. J. Colloid Interface Sci. 2012. 375(1): 154.

35. Purceno A.D., Teixeira A.P.C., Souza N.J.D., Fernandez-Outon L.E., Ardisson J.D., Lago R.M. Hybrid magnetic amphiphilic composites based on carbon nanotube/nanofibers and layered silicates fragments as efficient adsorbent for ethynilestradiol. J. Colloid Interface Sci. 2012. 379(1): 84.

36. Saleh T.A., Gupta V.K. Photo-catalyzed degradation of hazardous dye methyl orange by use of a composite catalyst consisting of multi-walled carbon nanotubes and titanium dioxide. J. Colloid Interface Sci. 2012. 371(1): 101.

37. Eder D. Carbon nanotube-inorganic hybrids. Chem. Rev. 2010. 110(3): 1348.

38. Lebovka N., Lisetski L., Bulavin L. Organization of Nano-disks of Laponite ${ }^{\circledR}$ in Soft Colloidal Systems. In: Modern Problems of the Physics of Liquid Systems. (Springer, 2019). P. 137.

39. Savenko V., Bulavin L., Rawiso M., Loginov M. Sedimentation stability and aging of aqueous dispersions of Laponite in the presence of cetyltrimethylammonium bromide. Phys. Rev. E. 2013. 88(5): 52301.

40. Manilo M., Lebovka N., Bárány S. Electrokinetic study of impact of laponite platelets on stabilization of carbon nanotubes in aqueous suspensions. Mater. Sci. Eng. 2015. 40: 96.

41. Manilo M.V., Lebovka N.I., Barany S. Aggregation in hydrid suspension filled by mixture of multi-walled carbon nanotubes and nanoplatelets of laponite. Mater. Sci. Eng. 2015. 40(1): 105.

42. Loginov M., Lebovka N., Vorobiev E. Hybrid multiwalled carbon nanotube ? Laponite sorbent for removal of methylene blue from aqueous solutions. J. Colloid Interface Sci. 2014. 431: 241.

43. Manilo M.V., Lebovka N.I., Barany S. Stability of multi-walled carbon nanotube + laponite hybrid particles in aqueous suspensions. Colloids Surf. A. 2015. 481: 199.

44. Manilo M., Lebovka N., Barany S. Mechanism of Methylene Blue adsorption on hybrid laponite-multi-walled carbon nanotube particles. J. Environ Sci. 2016. 42: 134.

45. Lebovka N. Aggregation of charged colloidal particles. In: Polyelectrolyte complexes in the dispersed and solid state: principles and applications. (Springer, 2014). P. 1.

46. Peigney A., Laurent C., Flahaut E., Bacsa R.R., Rousset A. Specific surface area of carbon nanotubes and bundles of carbon nanotubes. Carbon. 2001. 39(4): 507.

47. Laurent C., Flahaut E., Peigney A. The weight and density of carbon nanotubes versus the number of walls and diameter. Carbon. 2010. 48(10): 2994.

48. Fiyadh S.S., AlSaadi M.A., Jaafar W.Z., Al Omar M.Kh., Fayaed S.S., Mohd N.S., Hin L.S., El-Shafie A. Review on heavy metal adsorption processes by carbon nanotubes. J. Cleaner Prod. 2019. 230: 783.

49. Lian F., Chang C., Du Y., Zhu L., Xing B., Liu Ch. Adsorptive removal of hydrophobic organic compounds by carbonaceous adsorbents: A comparative study of waste-polymer-based, coal-based activated carbon, and carbon nanotubes. J. Environ Sci. 2012. 24(9): 1549.

50. Kerkez Ö., Bayazit S.S. Magnetite decorated multi-walled carbon nanotubes for removal of toxic dyes from aqueous solutions. J. Nanopart. Res. 2014. 16: 2431. 
51. Shahryari Z., Goharrizi A.S., Azadi M. Experimental study of methylene blue adsorption from aqueous solutions onto carbon nano tubes. International Journal of Water Resources and Environmental Engineering. 2010. 2(2): 16.

52. Szlachta M., Wójtowicz P. Adsorption of methylene blue and Congo red from aqueous solution by activated carbon and carbon nanotubes. Water Sci. Technol. 2013. 68(10): 2240.

53. Yan Y., Zhang M., Gong K., Su L., Guo Zh., Mao L. Adsorption of methylene blue dye onto carbon nanotubes: a route to an electrochemically functional nanostructure and its layer-by-layer assembled nanocomposite. Chem. Mater. 2005. 17(13): 3457.

54. Li Y., Du Q., Liu T., Peng X., Wang J., Sun J., Wang Y., Wu Sh., Wang Z., Xia Y., Xia L. Comparative study of methylene blue dye adsorption onto activated carbon, graphene oxide, and carbon nanotubes. Chem. Eng. Res. Des. 2013.91(2): 361.

55. Ma J., Yu F., Zhou L., Jin L., Yang M., Luan J., Tang Y., Fan H., Yuan Zh. Enhanced Adsorptive Removal of Methyl Orange and Methylene Blue from Aqueous Solution by Alkali-Activated Multiwalled Carbon Nanotubes. ACS Appl. Mater. Interfaces. 2012. 4(11): 5749.

56. Norzilah A.H., Fakhru'l-Razi A., Choong T.S.Y., Chuah A.L. Surface Modification Effects on CNTs Adsorption of Methylene Blue and Phenol. J. Nanomater. 2011. 2011: 495676.

57. Qu S., Huang F., Yu S., Chen G., Kong J. Magnetic removal of dyes from aqueous solution using multi-walled carbon nanotubes filled with $\mathrm{Fe}_{2} \mathrm{O}_{3}$ particles. J. Hazard. Mater. 2008. 160(2-3): 634.

58. Madrakiana T., Afkhami A., Ahmadi M., Bagheri H. Removal of some cationic dyes from aqueous solutions using magnetic-modified multi-walled carbon nanotubes. J. Hazard. Mater. 2011. 196: 109.

59. Patent WO2013127938 A1. Loginov M., Lebovka M., Vorobiev E. Utilisation de nanotubes de carbone et d'argile minerale synthetique pour la purification d'eaux contaminees. 2013. 